\title{
Land Rights and Aboriginal Economic Development: Lessons from the Northern Territory
}

\author{
Jon Altman
}

$\Gamma$

The economic future of Aboriginal Australians in the Northern Territory (NT) will be significantly improved in the 21 st century if strategic gains in land ownership made in the late 20th century can be converted into economic development of that land. Such economic development will occur primarily through joint ventures with non-indigenous interests. Direct or indirect commercial enterprises are among the few available options, apart from direct government subvention, for bridging the current gulf in living standards between indigenous and non-indigenous Australians.

This article examines the potential for such a development by considering the economic lessons that can be learnt from the operations of the Aboriginal Land Rights (Northern Territory) Act 1976 (henceforth the Land Rights Act) over the past 17 years and the extent to which these lessons have been and can be incorporated into the Native Title Act 1993. The Land Rights Act has been very influential, and has been used as a benchmark, in negotiating native title legislation. Admittedly, the NT case has only limited applicability to the rest of Australia: nowhere else do indigenous people constitute 23 per cent of the population; nowhere else, with the possible exception of Western Australia, could they potentially own 49 per cent of a State or Territory; and nowhere else have their land interests been recognised in law for over 80 years.

\section{Historical Antecedents}

Land-rights law was introduced as an aspect of the progressive social policy of the Whitlam Labor Government of 1972-75. Federal intervention was limited to the NT primarily because at that time the Territory was administered from Canberra. NT land rights contained important financial provisions to facilitate Aboriginal economic development. These provisions were largely a legacy of decisions made in the early years of Commonwealth administration to restrict miners' access to Aboriginal reserves under the broad colonial policy of protection and preservation. 
From 1911, an unusual political economy existed of reserved land and associated controls over commercial development, especially mineral exploration of reserves. At the outset, the Commonwealth earmarked considerable tracts of land for Aboriginal people under Crown land ordinances. The Aboriginals Ordinance 1918 limited the access of non-Aboriginal people to declared reserves. Mining ordinances also denied the holders of miners' rights access to Aboriginal reserves, and prospecting was forbidden (Altman, 1983).

It was only in 1952, under the very different policy of assimilation, that restrictions on mining appeared likely to be lifted. In that year, bauxite, a mineral for which there was deemed to be a strategic need, was discovered in the Wessell Islands, part of the Arnhem Land reserve. Paul Hasluck, then Minister for Territories, instituted a process whereby Aboriginal people could benefit financially from mining on reserves. The talk in those days was about regional economic development rather than cultural or social issues. The Minister was adamant that the Administrator, who could now issue miners' rights for reserves, would do so only where significant mineral deposits were discovered: if mining went ahead on reserves Aboriginal people were to be compensated.

The Aborigines Benefits Trust Fund established in 1952 introduced mechanisms that still exist today, in modified form. First, despite the absence of statutory or common law recognition of Aboriginal land ownership - Aboriginal people owned neither the land nor the minerals - the new provisions allowed for returns from mining on reserves to be earmarked for use by Aboriginal people. Second, a double royalty of 2.5 per cent ad valorem (of the value of minerals) was levied if mining occurred on Aboriginal reserves. Yet it was not until the early 1970s that an administrative mechanism was established to ensure that those who directly bore the economic, social and cultural costs associated with mining actually received a share of royalty payments or that such payments were linked to actual costs incurred. Under these provisions mining companies were penalised for mining on reserves, a disincentive that the Minister established in order to discourage smallscale and piecemeal development.

Policy intentions do not necessarily match outcomes. Mining did not eventuate in 1952, but began on Groote Eylandt in 1965. Manganese deposits were discovered on the island and the Church Missionary Society (CMS) took out prospecting rights on behalf of Aboriginal residents of the reserve. Subsequently, BHP successfully negotiated with CMS to give up its prospecting rights in exchange for a negotiated royalty: BHP was willing to pay not only the double royalty of 2.5 per cent ad valorem, but also an additional 1.25 per cent. At Gove, on the other hand, Nabalco was unwilling to pay the statutory double royalty to mine a massive bauxite deposit; but the Commonwealth's desire to open the mine resulted in the passage of a special ordinance that incorporated an output-based statutory royalty that converted to only about 1 per cent ad valorem. The passage of this ordinance resulted in the unsuccessful attempt by Yirrkala Aborigines to halt mining through the NT Supreme Court. 


\section{Financial Aspects of Land Rights}

A central paradox of the Land Rights Act is that it is financed from mining activity on Aboriginal land. This aspect of the legislation is poorly understood. In 1977, with the passage of the Act, former reserves were transferred to Aboriginal ownership. The expansion of the Aboriginal land base through the claims process has been largely funded from statutory so called 'mining royalty equivalents'. This clumsy term was invented when it became more widely recognised that Aboriginal people did not receive mining royalties, as had generally been thought, but received their equivalents paid from consolidated revenue (Altman, 1983:48). This change occurred because financial provisions of the Land Rights Act were enacted at the same time as the NT became self-governing. Consequently, mineral rights (and associated royalty rights) for all minerals, except uranium, were vested with the NT.

The operations of the Aboriginals Benefit Trust Account (ABTA), the institutional mechanism created to both distribute and accumulate statutory mining royalty equivalents, are complicated. There are two mineral ownership regimes in the NT. The ownership of uranium is vested with the Commonwealth; ownership of other minerals is vested with the NT. 'Statutory royalty equivalents' are paid to the ABTA, though all agreements have additional negotiated financial components. The income of the ABTA consists of these royalty equivalents from consolidated revenue and from investment income earned on accumulated funds. While from the ABTA's perspective there is no difference between uranium and non-uranium royalty equivalents, from the Commonwealth's perspective there is one major difference. As uranium royalties are paid to the Commonwealth, their transfer to the NT merely represents income forgone; but non-uranium royalties represent a net cost as the Commonwealth has to pay the equivalent of royalties that the consolidated revenue does not receive.

The payments out of the ABTA are mainly of three broad types defined under s.64 of the Land Rights Act. These accounted for $\$ 299 \mathrm{~m}$, or 91 per cent of the ABTA's income of $\$ 327 \mathrm{~m}$ (in nominal terms), in the period 1978-79 to 1993-94. Most of the balance has been saved, although some has also been spent to meet the administrative expenses of the ABTA itself.

The least discretionary payments are those to incorporated groups whose members are traditional owners of, or residents in, areas affected by mining, although the geographic jurisdictions of such areas have never been precisely defined. It is land councils that determine how these moneys will be divided between regional incorporated groups, often termed 'royalty associations'. These payments account for 30 per cent of the royalty equivalents received with respect to any particular resource development project. Over the period $1978-79$ to $1993-94, \$ 89 \mathrm{~m}$, or 27 per cent of ABTA income, was paid to a growing number of incorporated groups in 'areas affected' through land councils.

Payments to land councils to meet their operational expenses are also largely non-discretionary. Land councils are statutory authorities established by Commonwealth law with legally specified functions. This is not to say that they are not very unusual statutory authorities, primarily because they are openly, and at times ex- 
tremely, political. Their budgets are submitted for approval to the Minister for Aboriginal and Torres Strait Islander Affairs. Forty per cent of ABTA royalty equivalent income is earmarked for land councils' operational costs; but if approved budgets exceed this amount, additional resources can be made available under s.64(7) — so called 'supplementary funding'. Conversely, if earmarked payments to land councils exceed approved budgets, these 'surpluses' must be distributed. During the period 1978-79 to 1993-94, land councils received $\$ 152 \mathrm{~m}$ to meet their operational expenses. This amount accounted for 46 per cent of ABTA income. The costs of land councils have been politically contentious; but it has been argued that these costs could have been limited to 40 per cent but for the impost of an inequitable mining withholding tax (Altman, 1985; Australian National Audit Office, 1993).

Payments made as grants to be used to, or for, the benefit of Aboriginal people residing in the NT are discretionary, being based primarily on the recommendations of an all-Aboriginal Advisory Committee. While $\mathrm{Mr}$ Justice Woodward (1974) recommended that these payments should account for 30 per cent of the ABTA's receipts, over the period $1978-79$ to $1993-94$ they have totalled $\$ 58 \mathrm{~m}$, or 18 per cent of the ABTA's total income. These payments are arguably intended to compensate Aboriginal people who do not own land in the NT, but since 1989 a high proportion of these moneys have been used to purchase pastoral stations that have then become eligible for land claim.

\section{Evaluating Financial Aspects of Land Rights}

The utilisation of moneys paid to 'areas affected' has rarely been rigorously assessed. There is evidence that in some situations impressive and strategic regional developments have occurred, most notably at Kakadu National Park through the Gagudju Association (Altman, 1983; O'Faircheallaigh, 1986), but also in central Australia via the Ngurratjuta Association (Marshall, 1994). There is also evidence of some notable failures, in terms of regional economic development, as with the Kunwinjku Association in Western Arnhem Land (O'Faircheallaigh, 1988; Altman \& Smith, 1994). Some discretion is possible in the allocation of moneys to areas affected, but the Commonwealth and land councils are evidently reluctant to scrutinise the operations of so-called 'royalty' associations (a misnomer as all receive additional income from agreement and rental payments). Some consideration needs to be given to defining 'affectedness' and to specifying how mining moneys should be utilised to ameliorate any negative impacts of resource development projects.

Whether the $\$ 152 \mathrm{~m}$ paid to the NT land councils to claim and manage Aboriginal land has been optimally spent is a complex issue. Like all statutory bureaucracies, land councils differ in their levels of efficiency (see Australian National Audit Office, 1993, with respect to the Northern Land Council), but given their wider political activities they will generally seek to maximise their ministerially-approved budgets. Whatever the cost, there is little doubt that the transfer of land to indige- 
nous interests by means of the claims process is a redistribution of a key factor endowment that is potentially of immense economic significance.

In 1977, 258,000 sq kms of then existing reserves were scheduled and transferred to inalienable Aboriginal title. This represented 19 per cent of the NT. By March 1995, the Aboriginal land base had more than doubled to $549,000 \mathrm{sq} \mathrm{kms}$ or 41 per cent of the NT: some of this expansion occurred owing to negotiated NT title to land $(12,000 \mathrm{sq} \mathrm{kms})$. But most of the expansion was due to successful claims that expanded the Aboriginal land base by $272,000 \mathrm{sq} \mathrm{kms}$, almost all of which was unalienated Crown land. It is estimated that once the claims process is completed (new claims cannot be lodged after 1997) Aboriginal land could cover 49 per cent of the Territory.

The granting operations of the ABTA have been most closely monitored, primarily because the ABTA has been located within the Aboriginal affairs bureaucracy and has been very accessible to scrutiny. It has been reviewed on a number of occasions (for example, Altman, 1985; Crough, 1989; Walter \& Turnbull, 1993) and each time it has been criticised primarily not only for lacking appropriate financial and expenditure policies, but also for making grants in contravention of its own policies. Blame has invariably been laid with the ABTA Advisory Committee, but rarely with the Commonwealth Minister or his delegates. A key criticism made of the ABTA as a Trust Account, especially by the Australian National Audit Office, is that it has a poor savings and investment record: its accumulated reserves at 30 June 1994 totalled $\$ 31 \mathrm{~m}$ (in nominal terms) or 9 per cent of income. However, such concern may be misplaced as there is no statutory requirement for the ABTA to save; indeed, Woodward's (1974) recommended 40:30:30 formula merely treated the $\mathrm{ABTA}$ as a clearing house.

The fact that the ABTA retains income only after the payment of nondiscretionary areas-affected moneys and land-council administration expenses has not only marginalised its operations, but has also placed it in an unfortunate adversarial relationship with land councils, whose supplementary funding directly impinges on resources available to the ABTA Advisory Committee for granting purposes. The ABTA itself is in an invidious position. When it responsibly provides grants to purchase pastoral stations for Aboriginal people it is criticised for providing a means under the Land Rights Act to convert these stations to inalienable Aboriginal freehold title. But when it responds to Aboriginal priorities, like providing grants for the purchase of vehicles, it is criticised as irresponsible.

One of the continual tensions that has influenced the ABTA's granting operations is that between the policy of self-determination, which emphasises that grants should be made according to Aboriginal prerogatives and has resulted in high expenditure, and the economic rationality of accumulation. In 1984 it was recommended that the ABTA should become a peak organisation that operated as an independent statutory authority to manage financial aspects of the Land Rights Act (Altman, 1985:26-9); but this recommendation was never implemented. In 1995, the ABTA's granting operations, which remain under closer ministerial control than 
the Aboriginal and Torres Strait Islander Commission (ATSIC) itself, are looking increasingly anachronistic.

The financial provisions in the Land Rights Act should be radically recast. Options that have been raised, but rarely seriously debated, have included: funding of land councils directly from consolidated revenue; establishing the ABTA as an overriding statutory authority that manages all financial resources raised from commercial activity on Aboriginal land, but also has statutory functions to develop that land; specifying the role of 'areas affected' moneys in statute; specifying the means to accumulate development capital if this is regarded as a priority; and the abolition of grants from the ABTA if these are duplicating either the granting activities of ATSIC or the land-claims activities of land councils.

\section{Land Rights Lessons and Native Title}

In implementing native title legislation, there are economic lessons to be learnt from the NT experience. An important part of the Native Title Act 1993 is the establishment of a National Aboriginal and Torres Strait Islander Iand Fund that will be used to purchase land for those whose native title has been totally extinguished; pastoral lands purchased will be convertible to native title in much the same way as Aboriginal-owned stations in the NT can be claimed under the Land Rights Act. The operations of the ABTA will be especially instructive. In particular, there are indications that the ABTA has had great difficulty in accumulating sufficient reserves to establish a sustainable capital base. If accumulation is an objective, then it will be necessary to incorporate a savings ratio in statute, as was recommended for the ABTA in 1984 (Altman, 1985) and as has occurred after amendment in 1986 to the New South Wales Aboriginal Land Rights Act 1983.

The pressure to purchase land will obviously remain a priority when the $\mathrm{Na}$ tional Aboriginal and Torres Strait Islander Land Fund is operational, but consideration has to be given to the resources needed to develop the land. Perhaps the Commonwealth should separately earmark resources for land purchases and for land development. The ATSIC Commercial Development Corporation provides an appropriate conduit to facilitate commercial joint ventures on land owned by indigenous Australians. Quarantining of resources could provide the means to finance indigenous equity stakes in development.

The absence of any royalty payments in two recent mining agreements at $\mathrm{Mt}$ Todd and McArthur River suggests that active Aboriginal participation in resource development projects (as joint venturers, employees or contractors) may supersede a more passive 'rentier' role evident in previous NT mining agreements. The key difference in recent joint ventures is that Aboriginal interests hold significant equity stakes and matching representation on boards of management.

There are already indications, evident in these two agreements, that where mining companies and indigenous interests are willing to negotiate, with governments mediating, the outcomes can be positive for all parties. While neither agreement was conducted under the Native Title Act 1993 - the Mt Todd Agreement was completed in January 1993, prior to passage of the Act - both are in- 
structive because they were conducted in a political environment heavily influenced by the Mabo judgment. The Mt Todd agreement is especially important because it appears to have influenced, in turn, the drafting of the Native Title Act 1993 (Altman, 1994). The Mt Todd agreement is a deed signed by the NT government, Zapopan NL, a gold mining company, and the Jawoyn Association. In exchange for NT title (without any veto right) to a portion of land subject to a repeat claim by Jawoyn under the Land Rights Act, financial concessions from the NT government and a mining agreement with Zapopan, the Jawoyn agreed to withdraw this repeat claim and to surrender and extinguish any future native title claim to NT portion 3469 .

Economic and land benefits to Jawoyn include additional land under the Land Rights Act, development of an outstation, financial assistance for tourism facilities at Eva Valley, increased rentals for Nitmiluk (Katherine Gorge) National Park owned by Jawoyn, guaranteed employment opportunities, a bus-service contract and education scholarships to the Jawoyn. The Mirrkworlk joint venture between the Henry and Walker Group (50 per cent), the ATSIC Commercial Development Corporation ( 25 per cent) and the Jawoyn Association ( 25 per cent) won the major tender to mine and transport ore and waste to the Zapopan mill. There are options for a third of the Mirrkworlk workforce to be Jawoyn and the Association has the option to buy out the Commercial Development Corporation's share of the company.

In March 1994, an agreement was signed between the Commonwealth, the Northern Land Council (on behalf of Gurdanji, Yanyuwa and Mara people) and the Gurdanji-Bingbinga Corporation. This provided a package for local Aboriginal people, funded almost exclusively by the Commonwealth, in exchange for unhampered go-ahead for the McArthur River mining project. Benefits include the purchase and development of Bauhinia Downs pastoral station and a significant employment and training package to facilitate local employment in the mine. A joint venture company, Carpenteria Shipping Services, has been set up between the Commercial Development Corporation, Burns Philp and the Gurdanji-Bingbinga Corporation, and awarded the contract to barge silver, zinc and lead concentrates. There are options for up to 50 per cent of the company workforce to be Aboriginal and guaranteed training opportunities with Burns Philp.

These two agreements have been quite different. The McArthur River agreement is the more contentious, partly owing to diverse regional Aboriginal views and less leverage. The McArthur River agreement is inferior because neither the NT government nor the mining company, Mt Isa Mines, is a signatory; indeed, delays in the agreement resulted in lost opportunities for Aboriginal people that were to be financed by both. However, since local people have not withdrawn native title claims to offshore islands, certainty is less assured. Both agreements have resulted in positive outcomes for miners and Aboriginal interests, with limited net cost to government. The economic impact of both agreements for Aboriginal people and mining companies will need to be assessed; certainly, there are early indications that it might prove cost-effective for mining companies to recruit staff locally and to let 
contracts to competitive joint venturers with Commercial Development Corporation and regional Aboriginal equity.

\section{Conclusion}

An economic takeoff by the indigenous sector, Australia-wide, will not occur because of native title. Land alone cannot guarantee economic development: capital accumulation, human capital and entrepreneurial expertise will also be needed to promote the development of the indigenous land base. However, in the NT context, the leverage opportunities provided by the Land Rights Act, and now the Native Title Act 1993, have the capacity to create regional development options for Aboriginal people.

Some Aboriginal interests are increasingly recognising the need for new forms of joint ventures with indigenous equity participation, employment and training opportunities and buy-back options. The absence of automatic royalty payments in the Native Title Act 1993 framework may encourage a more active Aboriginal involvement in resource development projects. There is also a growing Aboriginal recognition that the payment of royalties to incorporated bodies in areas affected by mining can result in excessive regional politicking for these moneys, with a concomitant lack of attention to longer-term economic opportunities and an inability to accumulate venture capital for investment.

Such observations have been made in the past. But the fundamental difference in the mid-1990s is that economic lessons, from both failures and successes in the past, have been influential. It is increasingly recognised by key Aboriginal interests that the critical path to economic prosperity consists of the active participation of indigenous people, as significant stakeholders, in resource development. The Native Title Act 1993 provides a strong signal to take just such a route. Equity participation in resource development projects may not only provide the means to banish the negative stereotype of anti-development indigenous people, but may also demonstrate that, given genuine opportunities, indigenous people are pro-development.

\section{References}

Altman, J. (1983), Aborigines and Mining Royalties in the Northern Ternitory, Australian Institute of Aboriginal Studies, Canberra.

- (1985), Report on the Review of the Aboriginals Benefit Trust Account (and Related Financial Matters) in the Northem Territory Land Rights Legislation, AGPS, Canberra.

_ (1994), 'Economic Implications of Native Title: Dead End or Way ForwardP', in W. Sanders (ed.), Mabo and Native Title: Origins and Institutional Implications, Centre for Aboriginal Economic Policy Research, ANU, Canberra.

— \& D. Smith (1994), 'The Economic Impact of Mining Moneys: The Nabarlek Case, Westem Arnhem Land', Centre for Aboriginal Economic Policy Research, ANU, Canberra (CAEPR Discussion Paper 63). 
Australian National Audit Office (1993), Efficiency Audit Northern Land Council, AGPS, Canberra (Audit Report No. 20, 1993-94).

Crough, G. (Convener) (1989), 'Report on the Aboriginals Benefit Trust Account', unpublished report prepared for the Minister for Aboriginal Affairs, Economic and Social Policy Unit, University of Sydney.

Marshall, C. (1994), 'The Impact of Royalty Payments on Aboriginal Communities in the Northern 'Tenitory', in P. Jull et al. (eds), Surviving Columbus: Indigenous Peoples, Political Reform and Environmental Management in North Australia, North Australia Research Unit, Darwin.

O'Faircheallaigh, C. (1986), 'The Economic Impact on Aboriginal Communities of the Ranger Project, 1979-1985, Australian Aboriginal Studies 2: 2-14.

- (1988), 'Uranium Royalties and Aboriginal Economic Development', in D. Wade-Marshall \& P. Loveday (eds), Northem Australia Progress and Prospects, Volume 1: Contemporary Issues in Development, North Australia Research Unit, Darwin:

Walter \& 'Turnbull (1993), 'Report on an Internal Audit of the Aboriginals Benefit Trust Account', unpublished report to the Office of Evaluation and Audit, Aboriginal and Torres Strait Islander Commission, Canberra.

Woodward, A. (1974), The Aboriginal Land Rights Commission: Second Report, Apnil 1974, AGPS, Canberra.

This an abridged and updated version of a paper presented to the Mabo and Native Titles seminar held in Sydney in April 1994 under the sponsorship of the Macquarie University Mineral and Energy Economics Centre. I am grateful to Siobhan McKenna, three anonymous referees and the Editor for their comments on an earlier version of the article. 